\title{
The Place of the Local Councils in Decentralized Cooperation in Cameroon
}

\author{
Arnaud Ndi Abogso \\ Ngaoundéré University \\ Cameroon \\ Email: arnaudndilo [AT] yahoo.fr
}

The emergence ${ }^{1}$ of decentralized cooperation depends on the context. If in Europe, it was born with the aim of establishing contact between the State and local authorities. In the African context in general and Cameroon in particular, this emergence has been understood as a solution to the end of the double crises: the socio-political and economic crises.

The main form of decentralized cooperation was twinning ${ }^{2}$, with the difference that twinning does not maintain the concrete, while decentralized cooperation maintains an active or proactive concrete action stimulating development actions $^{3}$.

As a solution to the double political crisis with demands linked in the 1980s to the republican form of the state. It was necessary to include the latter in the requirements of institutional changes, and in this perspective that the change related, sometimes to the decentralization of the State, having regard to the concern for federalism of the Anglo-Saxon tradition, and sometimes to alleviate the concern of national union. The state ultimately opted by compromise for a decentralized unitary model. This platform, known as the tripartite ${ }^{4}$, was a political concession to stifle federalist inclinations in the English-speaking area, claiming State power ${ }^{5}$.

The second context of the emergence of decentralized cooperation constitutes a response to the ambient economic crisis of the 1980s, consecrated by the fall in raw materials, the drastic fall in the economic level of the State with a fall in the budget, the crisis in the paradigm of economic planning or five-year plans as economic factors of crisis. Hence the serious impact on the transfer of funds to local communities, unable to participate effectively in local development programs, today communal development plans (CDP), the state having failed. Decentralization thus appears to be a new approach in the fight against underdevelopment. This is why the structural adjustment ${ }^{6}$ plans will support local communities in the social dimension of the fight against poverty.

Thus, talking about the place of local authorities in decentralized cooperation in Cameroon seems more to be an illusion $^{7}$ than a glimmer, in the sense that the latter play only a very subsidiary role, even derisory in a process of agreement concerning them, in the first place. However, this place is decisive because, thereby confirming the autonomy of the decentralized bodies.

\footnotetext{
${ }^{1}$-Yves Claisse, Le droit de la coopération décentralisée, LGDJ, 1998, p.24.

2-Alain Marie, Coopération décentralisée et ses paradoxes. Dérives bureaucratiques notabiliaires du développement local en Afrique, Paris, Karthala 2005, p.52.

3. Franck Petite Ville, "La coopération décentralisée pour le développement ", thèse de doctorat, Université Pierre Mendes, France, IEP Grenoble, 1994, p.7.

4- Still called sovereign national conference and helth from $30^{\text {th }}$ October to $16^{\text {th }}$ November 1991 , Tripartite meeting, government/opposition/civil society intervenes in the context marqued with the demand of a national conference which appears in the eyes of the opposition like a political technology appropriated to try and limit the governmental monopoly in the definition of the rules of the political game. It is at the time of the opposition "Ghost towns" and the insurrectional climate prevailed in the town dominated by the opposition, and threatening the stability of the power. President Biya measuring the danger of a national conference proposed on the $11^{\text {th }}$ of October a meeting between the independent personalities. The object of the Tripartite was fixed in advance by the president, resident in the preparation of the pilot study of an electoral code and the definition of conditions and modalities of access to the Medias for all political parties.

5- It is advisable to underline the minority position of the federalists and secessionists. They are today minors, even hoarse. On the debate on time, read Menthong H-L, « La construction des enjeux locaux dans le débat constitutionnel au Cameroun ", Polis, Vol.2, n², 1996, p.69.

6- Philippe Hugon, "Incidences sociales des politiques d'ajustement », in Tiers-monde, Vol. $n^{\circ} 30, n^{\circ} 117,1989, p .70$.

${ }^{7}$-The structural deficits inherent to the Cameroonian State jeopardize more of decentralized unitary model than the implementation of the decentralized cooperation. See Bernard-Raymond Guimdo, "L'emprise de l'Etat sur l'exécutif communal au Cameroun (Regard sur la dynamique des rapports entre l'administration d'Etat et l'administration communale au Cameroun)», in Lex Lata, n²1, décembre 1995, pp.9-16.
} 
This problem is all the more relevant since local authorities constitutionally enjoy an autonomy which can enable them to act internationally within the framework of decentralized cooperation. The double handicap arises both in terms of financial ${ }^{8}$ autonomy and politico-administrative. According to the 2009 law, it is important to note that local taxation represents the main resource of local authorities, it is subdivided into three groups: municipal taxes and regional taxes and charges.

Communal taxes are the resources of fiscal origin issued and collected for the benefit of local communities by the state tax services. The municipal taxes allocated to local authorities are made up of: contributions from business licenses; license fees; property tax on real estate property; property transfer rights (property and lease); additional municipal centimes (AMC); parking tax; the annual forest royalty (AFR); local development tax (LDT); automotive stamp duty (ASD) and stamp duty on advertising (SDA). As for municipal taxes, these are resources generally derived from municipal services and which, although governed by fiscal law, are directly levied by the local authorities themselves. They include: the local development tax, the cattle slaughter tax, the firearms tax, the hygiene and sanitation tax, the market place rights, the rights on building permits or to set up, the temporary occupation rights of the public thoroughfare, the parking tax, the right to occupy parking lots, platform tickets, the tax on shows, stadium rights, stamp duty municipal, the charge for the degradation of the roadway, the municipal transit or transhumance tax, the tax on the transport of quarry products, the rights of parking, the tax on salvage products. Local authorities that do not have a certain amount of infrastructure cannot tax them.

This means that the tax varies depending on the municipal entity and the infrastructure it has. In addition to this external funding, local authorities receive two types endowments from the State: the general endowment for decentralization (GED) and the credits transferred. The first was established by the law of 20049 , providing for: "partial financing of decentralization" 10 and simultaneously specifies that: "the finance law fixes each year on a proposal from the government, the fraction of State revenue allocated to the endowment general of decentralization" 11 .

Contrary to the $2008^{12}$ decision, and to the general spirit of the $2009^{13}$ law, the municipalities do not benefit from considerable financial support within the framework of their international actions, anything limiting their participation in the decentralized cooperation process which, it should be remembered implies the pooling of resources in the realization of intermunicipal projects. Despite this legal illuviation ${ }^{14}$ and sometimes empty of substance, Cameroonian communities contribute only very partially, if not at all in the implementation of projects agreed with their foreign counterpart.

Cameroonian local authorities little anchored in the decentralization process of an assertorically centralized ${ }^{15}$ state, $^{-}$ enjoying only paper autonomy, and hardly participate in their liberalization and political emancipation movement. Most African states perceive their territorial dismemberments as potential threats ${ }^{16}$ because a priori inducing the weakening of their central power. However, decentralization would like us to consider local authorities from now on as true partners ${ }^{17}$ of the central state, capable of solving the problems they face, without being more dependent on the latter.

If it is true that the decentralized bodies are autonomous, they should be able to negotiate and sign conventions themselves with their foreign counterpart. The State's vicious grip on its territorial divisions goes against the canons and principles stemming from decentralization. The ultimate objective of administrative and territorial decentralization is to achieve effective autonomy for decentralized entities. However, in its current state, the autonomy of local Cameroonian political entities is a view of the mind, leading to their systematic subordination (P1), therefore one of the consequences is the structural slanting of Cameroonian local governance (P2).

\footnotetext{
8- Law $n^{\circ} 2009 / 019$ of 15 th December handling local taxation.

${ }^{9}$-Law $n^{\circ}$ 2004/017 of 22nd July 2004 handling the orientation of Cameroon decentralization.

10-Ibidem, article 33, indent 1.

11 -lbid., article 33 , indents 2.

12. Decision $n^{\circ} 002 / B I S / D / F E I C O M / C A$ of $21^{\text {st }}$ august 2008 , fixing the framework of FEICOM to the international actions of the councils (CAFAIC).

${ }^{13}$-Law $n^{\circ} 2009 / 011$ of $10^{\text {th }}$ July 2009 , handling financial regime of the decentralized territorial collectivities in Cameroon.

14-Victor Karady, "Une nation de juristes », in Actes de la recherche en sciences sociales, Vol, 86-87, mars 1991.

15- Barthélémy Kom Tchuenté, Développement communal et gestion urbaine au Cameroun. Les enjeux de la gestion municipale dans un système centralisé, Yaoundé, Clé, 1994, p.9.

16- V. BOURJOL, "L'état du fonctionnaire locale ", in La fonction publique locale, Acte du colloque Fontevraud (19-20 mai 1978), Paris, Cujas, 1979, p.133.

17- T. MICHALON, « La République française, une Fédération qui s'ignore ? ", RDP, 1982, pp.623-688.
} 
P1-The systematic subordination of decentralized local authorities in the agreement process. Beyond being dismemberments of the State, Cameroonian local communities are subject to subordination, or even an unbearable marginalization in the highlighting of the conventions signed with their foreign counterpart, within the framework of the decentralized cooperation.

In fact, local authorities are systematically and almost relegated to the background by the central state, or at least its central institutions with regard to agreement procedures and their implementation procedures. In principle, the main players ${ }^{18}$ in highlighting pre and post-conventional mechanics are local authorities. However, it is recurrent and curious to observe that the latter are not at the heart of the agreement process, because, relegated to the subsidiary plan by the tutelary institutions of the central State.

In doing so, local authorities rather undergo parameters dependent on the decentralization process, such as decentralized cooperation. The institutional functioning of the Cameroonian state suppresses the emergence of local government autonomy. The state steamroller rubs off on their operating capacities which are already sufficiently thickened by the standards in force in this area. This subalternation of local entities manifests itself essentially through the consecration of the theory of Bayartian dependence (A), and the financial extraversion of Cameroonian local political entities (B) whose realization of the agreed projects attests to this being sufficient.

\section{A-the consecration of the theory of dependence and the weight of extreme tutelarization.}

Before dwelling on this part, it is fitting to clarify the context of use of the conceptual block of the theory of dependence. Unlike the original content attributed to it by its author ${ }^{19}$ (Jean-François Bayart in the State in Africa, politics of the belly), the theory of dependence is used in the sense of the links of extreme dependence created by the State, with regard to its decentralized local authorities. Especially since this dependence is multidimensional ${ }^{20}$ (political, financial, administrative, institutional dependencies ...) because, interfering in almost all areas of the life of these entities. The decentralized finicky or paper $^{21}$ cooperation initiated by the Cameroonian state has not really resulted in real autonomy for local authorities.

In fact, this public policy as defined by Pierre Muller ${ }^{22}$ as the State in action, although ambitious, lies in the inbetween, in other words, between the frantic acclimatization to the conditionalities dictated by the international financial ${ }^{23}$ authorities and the need to consolidate the politico-institutional and politico-administrative power of the central state. This institutional weightlessness does not carry institutionally and administratively autonomous premises. The autonomy of an institution is not limited to a simple legal verbosity. It is its implementation that constitutes its real consecration.

Since the legal institutionalization of territorial and administrative decentralization in Cameroon in 2004, local entities do not always enjoy real autonomy, which constitutes a flagship principle, even an inescapable principle of territorial decentralization. If local authorities therefore hardly benefit from a minimum ${ }^{24}$ of autonomy, we cannot speak of decentralization, but rather of administrative deconcentration. However, from a constitutional point of view, the Cameroonian state has opted for a unitary decentralized and not deconcentrated State model. Consequently, there is a strong institutional frenzy 25 regarding the effective empowerment of local political entities.

Thus, the institutional structuring of Cameroonian state unity is made in such a way that local political entities, although claiming their autonomy, remain highly dependent on the central political power and their external partners.

\footnotetext{
18. L. FAVOREU, « Les bases constitutionnelles du droit des collectivités locales », in F. MODERNE (dir.), La nouvelle décentralisation, Paris, Sirey, 1983, p.30.

19- Jean François Bayart, L'Etat en Afrique, la politique du ventre, Paris, Fayard, 1989.

20 - Although they are broken up the entities of the State, the local authorities depend strongly on the central State especially on the financement plan.

${ }^{21}$-Pierre Muller, specialist of public policy he used to say that we evaluate the public policy on the gap between what it announced( what relieves from the speech) and the reality(what relieves from the facts), Pierre Muller, Les politiques publiques, Paris, PUF, 1990.

22-Ibid.

${ }^{23}$-Charles Nach Mback, "La décentralisation en Afrique : enjeux et perspectives », in Du Bois de Gaudesson J., Médard J-F (dir.), "L'Etat en Afrique : entre le global et le local », Afrique contemporaine, sept.2001, p.95.

${ }^{24}$-Roje Tadjie, "Le contrôle des collectivités territoriales au Cameroun », Cahiers juridiques et politiques, 2009, pp.213230.

25-J. Kankeu, « L'autonomie des collectivités territoriales : quelle autonomie ? » Juridis périodique, $n^{\circ} 85$, janvier-févriermars 2011, pp.90-99.
} 
At the administrative level, for example, most of the decisions, not to say all the decisions of certain importance ${ }^{26}$, are taken by the central government. Therefore, decisions of this nature must first be approved by the central political institutions. These logics of institutional pre-eminence between the institutions of the central state and those of its territorial dismemberments place them at the antipodes of all autonomy. This is the case for the praxis of decentralized cooperation insofar as any agreement to be signed between a local Cameroonian and foreign authority must first go through the agreement of the tutelary ministry which does not always have all the necessary elements of appreciating a potential intercommunity agreement. Therefore, any decision by a municipality must refer to the supervisory authority, sometimes to the detriment of local interest.

Admittedly, local authorities remain sub-state entities or inferior to the State, but the fact remains that their autonomy should enable them to take a certain number of decisions capable of preserving their interests, which are not mechanically identical ${ }^{27}$ to those of the central state.

The dependence of local communities on the state manifests itself more economically.

More than any other area, local entities depend economically and viscerally on the central state.

Indeed, the local entities, which are very weak ${ }^{28}$ economically, depend almost systematically on the central State within the framework of the general budgetary allocation allocated to decentralization. And this endowment responds only very partially to the problems of decentralized local entities.

In addition to the financial allocation allocated to local authorities, their revenues are also negligible; municipal taxes varying according to the type of municipal institution. A borough municipality cannot have the same amount of revenue compared to that of a giant like the urban community. The area and the municipal configuration are also taken into account. Moulded in this shackles of financial excitement, Cameroonian local political entities are doomed to reach out to the smallest opportunity that can bring them either financial or infrastructural well-being.

The table above tends to demonstrate this dependence of local authorities, especially with regard to their European counterpart. and the bank of municipalities, known as FEICOM, here is the summary obtained after survey and compilation in the ten regions of Cameroon:

\section{1-NORTH REGION}

Number of local councils (LC): 21

Urban council: 01

Subdivisions councils: 03

Councils: 17

Councils associations: 02

Council's trades: 01

Partnerships: nothing.

\section{2-FAR NORTH REGION}

Number of local council: 48

Urban council: 01

Subdivisions council: 03

Councils: 44

Council associations: 03

Council trade: 01

Partnerships: 04

With Spain: 02

France: 01

Italy: 01

\footnotetext{
26- Raymond-Bernard Guimdo, op.cit, p.29.

27- Martin FINKEN, Commune et gestion municipale au Cameroun, Ed. F. Martin, Yaoundé, 1996, pp.51-52.

${ }^{28}$-Unlike others types of councils, the urban councils are capable of mobilizing substantials financial resources in terms of hundred millions, even billions of francs CFA.
} 


\section{3-ADAMOUA REGION}

Number of local council: 22

Urban council: 01

Subdivisions council: 03

Councils: 18

Council trade: 00

Council associations: 02

Partnerships: 02

With France: 01

Norway: 01

\section{4- CENTRE REGION}

Number of local council: 71

Urban council: 01

Subdivisions council: 07

Councils:63

Council trade: 03

Partnerships: 23

With France: 10

Italy: 01

Greece: 01

China: 01

Congo: 01

Cameroon: 08(06 with nongovernmental organisations and associations).

\section{5-WEST REGION}

Number of local council: 41

Urban council: 01

Subdivisions council: 03

Councils: 37

Council associations: 03

Council trade: 00

Partnerships: 18

With France: 11

Italy: 04

European Union: 01

Cameroon: 01

\section{6-EAST REGION}

Number of local council: 34

Urban council: 01

Subdivisions council: 02

Councils: 30

Council associations: 02

Council trade: 02

Partnerships: 05

With France: 02

Netherlands: 01

Belgium: 01

Cameroon: 01 


\section{7-NORTH WEST REGION}

Number of local council: 35

Urban council: 01

Subdivisions council: 03

Councils: 31

Council associations: 01

Council trade: 00

Partnerships: 25

With Netherlands: 01

South Korea: 01

23 with national and foreign associations

\section{8-SOUTH REGION}

\section{Number of local council: 31}

Urban council: 02

Subdivisions council: 04

Councils: 25

Council associations: 02

Council trade: 00

Partnerships: 04

With France: 03

Republic of Congo: 01

\section{9-SOUTH WEST REGION}

Number of local council: 33

Urban council: 02

Subdivisions council: 06

Councils: 25

Council associations: 02

Council trade: 00

Partnerships: 06

With France: 04

United Stated: 01

China: 01

\section{0-LITTORAL REGION}

Number of local council: 37

Urban council: 03

Councils: 25

Council associations: 02

Council trade: 02

Partnerships: 13

With France: 09

Italy: 01

Belgium: 01

Switzerland: 01

Source: Author's investigation and compilation.

A real and not fictitious autonomy would have allowed sub-state entities to have a free hand to conquer ${ }^{29}$ other sources of income and to legitimately meet their needs. And the autonomous retention of local communities by the State is made, on purpose insofar as, the granting of effective autonomy would substantially reduce this multidimensional dependence.

Local authorities are subject to very meagre financial rationing, which can be explained, on the one hand, by the absence of their autonomy, favouring an inconsistent deployment in the quest for resources. Thus, any mobilization, especially with an external vocation, must first pass through the approval of the central political power.

${ }^{29}$-See decree $n^{\circ} 2011 / 1116 / P M$ of $26^{\text {th }}$ April 2011 fixing the modalities of decentralized cooperation in Cameroon. 
Externally, the dependence of Cameroonian local authorities is characterized by the materialization phase of joint projects with their external counterpart.

In fact, during the implementation of so-called joint projects, dependent on the agreement duly signed, we peacefully note that $3 / 4^{30}$, or even all of the funds come from the external community. However, in the conventional ${ }^{31}$ framework, it is stipulated that each stakeholder or related party must bear half of the costs during the execution of the project. Sometimes lacking in operating resources, Cameroonian local authorities are subject to dependence on their external counterpart.

\section{B-The financial extraversion of Cameroonian local authorities}

The unrestrained quest for resources from local Cameroonian political entities forces them to be deployed externally or externally. The general budgetary allocation to them granted by the State and their revenues are subject to meagre financial rationing. Decentralized cooperation has emerged as a real field of opportunity for these local entities in crisis ${ }^{32}$ of financial income. This frenzy over the creation of ties of cooperation with their external counterpart, especially those of Western origin, reduces them to a position of subjugation. However, any praxis of decentralized cooperation is intended to be reciprocal, with a view of balancing partnership in the realization of joint projects agreed by the related parties.

Thus, we observe a financial extraversion of most of the decentralized African local authorities in general, and Cameroonian in particular towards Europe because they are more fluid in terms of financial income. However, decentralized cooperation is hardly a restrictive concept extra continental; it can also be practiced between African municipalities. However, as it stands, very few ${ }^{33}$ African local authorities cooperate with one another in the framework of decentralized cooperation. Almost all of these local entities rather rush towards their Western European comrades.

In this perspective, Cameroonian local authorities are incorporated in the assisted ${ }^{34}$ register, because nature and the aid which always comes from the north, puts them in a dependency posture vis-à-vis the countries of the north. And this demonstrates the extraversion of these municipalities in cooperation.

In the absence of a rigorous or even rigid implementation of the canons of decentralization, local entities are constantly looking for external financial resources. However, behind this apparent charity of Western sub-state entities prostrates a promoted and exhibited ideology, among others liberalism, the universalizing ${ }^{35}$ propensity of the Western democratic model, respect for human rights. This confirms, moreover, the Maussian ${ }^{36}$ theory of gift and counter-gift, so the latter can be just as well, material as symbolic. By mainly funding the projects, however common, resulting from the agreement signed between them and their African counterpart, Western local authorities expect a return from the elevator, be it ideologically or symbolically.

This means that, in the context of structuring the links between states, infra or even para-state entities, the paradigm of aid, especially of public interest, must be systematically evacuated. Notion still potentially valid in basic social units such as the family.

The financial vulnerability of African local authorities in general, and Cameroonian in particular, puts them in a position of double dependence, the first being relative to the central state, and the second relating to the external financial windfall, their Western-centric counterpart.

However, the essence of decentralized cooperation is the pooling of resources, both financial and technical, in order to carry out joint projects. There is no unilateral decentralized cooperation, that is to say led and oriented by only one part.

\footnotetext{
30- The quasi-totality of projects issued from the conventions signed between the Cameroonian local collectivities and western are realized by the western local collectivities.

31- See decree 2011 fixing the modalities of decentralized cooperation in Cameroon, op.cit.

32- It talks mainly about the scarcity of financial resources which express by the small dotation of the general budget given to the decentralized territorial collectivities by the State.

33- See Figure 1, compilation and investigation of the author on the panorama of the actions of the decentralized cooperation of the Cameroon councils.

34-Franck Petite Ville, op, cit, p.38.

${ }^{35}$-Bertrand Badie, L'occidentalisation de l'ordre politique, Paris, Fayard, 1992, p.20.

36-Marcel Mauss, cité par Christophe Moundou et Aymeric Potteau, Action extérieure des collectivités locales- bilan et perspectives, Paris, L'Harmattan, 2004, p.18.
} 
It in fact implies reciprocity and pooling of resources between the different actors involved. All subodorant financial unilateralism, hence a hierarchy disclosed in cooperative practice. The predominant financial position of the decentralized external entities gives them the opportunity to occupy a hegemonic ${ }^{37}$ rank vis-à-vis their African partners, thus sometimes showing excessive paternalism. This relationship which takes on the appearance of a master-slave ${ }^{38}$ relationship does not always honour Cameroonian local entities insofar as they will have more autonomy and therefore more resources and less dependent on the central State and of the external room. And this financial gloom also explains, was it partially the rapid abandonment of the practice of twinning by Cameroonian local entities, and in favour of decentralized cooperation. Because, unlike twinning, which was more symbolic and diplomatic-cultural, it did not really meet the needs of the populations.

However, decentralized cooperation is intended to be more concrete, pragmatic, and capable of giving more or less satisfactory responses to the territorial dismemberments of developing States. It is in this perspective that European local authorities, in particular decided to pool their efforts through the channel of decentralized cooperation, which has been called $^{39}$ decentralized cooperation for development ${ }^{40}$. It makes Cameroonian local authorities beneficiaries of the projects carried out, by their foreign counterpart. Although not very large-scale projects, this position occupied by local communities places them in a dependency paradigm with respect to western local communities. From this perspective, all cooperative practice falls within the framework of a unilateralism dominated by European sub-state political entities.

The beginnings of Cameroonian decentralization only reinforce this state of affairs. The acquisition of an economic and financial fabric first requires that of real autonomy for decentralized entities. The latter allows them to conquer resources both internally and externally from the state to which they belong.

This is not synonymous with total or absolute independence. The State still assumes its supervisory role, but further liberalizes all sectors of the social life of local authorities. Its excessive presence notoriously slows down or weakens the capacity for cooperation that a local authority can and wants to deploy, because all the necessary approvals passes through its central politico-administrative institutions. Anything rubbing off, considerably on the process of empowering territorial divisions and therefore their pursuit remains socio-economic and socio-infrastructural development, in flagrant violation of the principles structuring municipal governance in Cameroon.

The table below presents the decentralized cooperation actions undertaken by the Cameroonian local authorities within the framework of the conventions signed with their foreign counterpart.

\begin{tabular}{|l|l|l|l|l|}
\hline $\begin{array}{l}\text { Foreign } \\
\text { councils }\end{array}$ & $\begin{array}{l}\text { Cameroonian } \\
\text { councils }\end{array}$ & $\begin{array}{l}\text { Date of convention } \\
\text { signature }\end{array}$ & Domains & Realisations \\
\hline Helvetas(Switzerland) & Njinikom & April 2005 & Infrastructure & $\begin{array}{l}\text { Construction of bust } \\
\text { station }\end{array}$ \\
\hline Helvetas & Belo & May 2006 & $\begin{array}{l}\text { Construction of twenty } \\
\text { two sales counters in the } \\
\text { market, construction of } \\
\text { classrooms at } \\
\text { Ngensumbu et Anyajua. }\end{array}$ \\
\hline VSO(Great Britain) & Belo & July 2005 & Training & $\begin{array}{l}\text { Sending of American } \\
\text { volunteers to train and } \\
\text { accompany the mayors } \\
\text { and communal agents. }\end{array}$ \\
\hline Helvetas & Fundong & - & $\begin{array}{l}\text { Education } \\
\text { potable water }\end{array}$ & $\begin{array}{l}\text { anstruction } \\
\text { classrooms, } \\
\text { construction of drilling } \\
\text { water at Abuh and } \\
\text { Iseabuh. }\end{array}$ \\
\hline
\end{tabular}

\footnotetext{
37-Ibid.

38 -lbid.

${ }^{39}$-Franck Petite Ville, op.cit, p.34.

${ }^{40}$-lbid., p.52.
} 


\begin{tabular}{|c|c|c|c|c|}
\hline Helvetas & Batibo & $13^{\text {th }}$ august 2010 & Potable water & $\begin{array}{l}\text { Construction and fitting } \\
\text { out of potable water } \\
\text { network at Enyoh, } \\
\text { Oshum, Efah, Bessi et } \\
\text { Kuruku. }\end{array}$ \\
\hline VSO & Tubah & $18^{\text {th }}$ June 2008 & $\begin{array}{l}\text { Training, Health, } \\
\text { electrification }\end{array}$ & $\begin{array}{l}\text { Equipment } \\
\text { municipalities in } \\
\text { computer material, offer } \\
\text { of solar panel in } \\
\text { Kedjomkeku village, } \\
\text { refunding of mayor } \\
\text { travelling. }\end{array}$ \\
\hline $\begin{array}{l}\text { Dordrecht } \\
\text { council(Netherlands) }\end{array}$ & $\begin{array}{l}\text { Bamenda urban } \\
\text { council }\end{array}$ & $\begin{array}{l}22^{\text {nd }} \quad \text { September } \\
2009\end{array}$ & $\begin{array}{l}\text { Infrastructure, } \\
\text { Health }\end{array}$ & $\begin{array}{l}\text { Bridges construction of } \\
\text { Ndefru, Ntakah, health } \\
\text { centers equipment of } \\
\text { Bamenda Kwen, } \\
\text { Alabokam, Ntakah in } \\
\text { beds, chairs and potable } \\
\text { water. }\end{array}$ \\
\hline Veolia Foundation & Bangangte & 2010 & Social & $\begin{array}{l}\text { Construction of } \\
\text { ecological latrines, } \\
\text { training of latrines } \\
\text { constructors, acquisition } \\
\text { of one pick-up. }\end{array}$ \\
\hline Foenang council & Bangangte & 2011 & Education & $\begin{array}{l}\text { Project of one text book } \\
\text { per bench in the schools } \\
\text { of Bangangte. }\end{array}$ \\
\hline Thann town & Bafia & $7^{\text {th }}$ December 2010 & Education & $\begin{array}{l}\text { Education for } \\
\text { development, socio- } \\
\text { cultural exchanges }\end{array}$ \\
\hline Selestat town & Sa'a & $19^{\text {th }}$ January 2011 & Urban development & $\begin{array}{l}\text { Acquisition of } \\
\text { construction material, } \\
\text { cleaning-up, fitting. }\end{array}$ \\
\hline Villeneuve town & Yaounde 4 & $12^{\text {th }}$ February & $\begin{array}{l}\text { Culture, } \\
\text { infrastructure }\end{array}$ & $\begin{array}{l}\text { Orphanage } \\
\text { rehabilitation, } \\
\text { orphanage construction, } \\
\text { gift of five hundred text } \\
\text { books in Government } \\
\text { High School of } \\
\text { Anguissa. }\end{array}$ \\
\hline Colombes council & Yaounde 2 & 2010 & $\begin{array}{l}\text { Infrastructure, } \\
\text { cleaning-up. }\end{array}$ & $\begin{array}{l}\text { Realisation of a picking- } \\
\text { up water project at } \\
\text { Messa-carrière. }\end{array}$ \\
\hline $\begin{array}{ll}\text { Hauts de } & \text { Seine } \\
\text { department }\end{array}$ & Belel & 2006 & Health, education & $\begin{array}{l}\text { A health center } \\
\text { equipped and electrified } \\
\text { with the first stock of } \\
\text { medicine, an equipped } \\
\text { drilling water and } \\
\text { construction of two } \\
\text { classrooms with latrines } \\
\text { at public school of } \\
\text { Djilougou. }\end{array}$ \\
\hline
\end{tabular}

Source: Author's investigation and compilation. 


\section{P2- The structural slanting of local governance.}

Dependent on the vices ${ }^{41}$ linked to legal texts and standards relating to decentralization in particular, and of a locally reconfigured ${ }^{42}$ unitary decentralized state. The praxis of local governance has enormous slanting. in the Cameroonian context. Indeed, the absence of local autonomy multiplies strangulation links in its relations with the central state. These reports, mostly of institutional subordination, are not likely to lead to credible governance of the Cameroonian municipal institution. They convey numerous pitfalls and obstacles to the proper functioning of the municipal institution. The ineffectiveness of decentralization and therefore of local self-government keeps state dismemberments under the heavy tutelage of central political and institutional power.

The institutionalization or at least the movement of municipalization took place in a context of strong political and institutional central excitement which required the involvement of a peripheral level. This institutional peripherization ${ }^{43}$ took place under several manifest and latent conditionalities of the central state; therefore, one was the strengthening of central power. In this perspective of political utopia, this is why, we still observe the appointment of Cameroonian municipal executives (A), and the reign of political autochthony which results from it (B).

\section{A-The issue of appointment of municipal executives.}

One of the key criteria ${ }^{44}$ of territorial decentralization is the election of decentralized bodies. However, if one legally ${ }^{45}$ names certain decentralized bodies, one is in the presence of a flagrant violation of the universal principles of decentralization.

The State of Cameroon is experiencing a huge obstacle in its process of municipalization. Before the law of $1987^{46}$, municipal executives were elected regardless of the municipal district. The aforementioned decree then overturned the structuring of the local institutional field. By conferring on the president of the republic the nominative power of the municipal executives and not least, those who head the largest local institutions, in this case the urban communities.

Thus, the act of appointment is undemocratic from the point of view of the principles regulating decentralization. Anybody resulting from decentralization is supposed to be the product of the people, in other words, elected at the end of a more or less democratic electoral process. Consequently, that these principal minima of decentralization are not observed, we are rather in the presence of an administrative deconcentration.

The tutor of the State with regard to its dismemberments is metamorphosed rather into a steamroller which leaves no margin of autonomy to local political entities. Without the latter, we cannot speak of administrative decentralization, even less territorial. The autonomy of decentralized bodies being one of the keys to decentralization.

Under these conditions, the Cameroonian state is implementing decentralization preceded by municipalization with variable geometry ${ }^{47}$.

On the one hand, we have decentralized bodies fully elected by democratic procedures. On the other hand, bodies entirely appointed by the head of state, which leads to totally ambivalent ${ }^{48}$ decentralization within the same state entity.

But, obviously, the appointment of government delegates, real bosses of mayors in urban areas, skews the Cameroonian decentralization from top to bottom. This appointment of municipal executives therefore seems to be a thorn in the face of decentralization in Cameroon, especially since government delegates exercise all the attributes of legitimately

\footnotetext{
41-Jean Njoya, "Les mutations politiques en Afrique : la trajectoire erratique de l'élu local au Cameroun », in Revue Africaine de sciences juridiques et politiques au Cameroun, Vol. 26, n41, 2006, p.19.

42 -Ibid, p.21.

43. James S. Coleman, "The concept of political penetration", Government and rural development in East Africa. Essays

On political penetration, ed. by L.Cliffe, J.S Coleman and Martin R. Dooribos. The Hague Martinus Nijhoff, 1977, p. 18.

44. Charles Roig, "Théorie et réalité et de la décentralisation », in Revue française de science politique, Vol.16, $n^{\circ} 3$, 1966, p.464.

45 - Law $n^{\circ} 87 / 015$ of 15 th July 1987 handling creation of urban councils.

46-Ibidem.

${ }^{47}$-This gap is more ostentatious on the geographical, financial and administrative plans between the subdivisions councils and the urban councils.

48-Difference between councils and urban councils. To bring back essentially on the text laws on 2004 on the orientation of the decentralization and that fixing the rules applicable to the councils.
} 
and democratically elected mayors. This decentralized bifaciality ${ }^{49}$ situated at the democratic antipodes can only with great difficulty honour the democratic ethics of the Cameroonian State. And this gives rise to a democratic scrambling insofar as those who are elected become subordinates of the nominees, or both categories of actors exercise in principle elective functions. It is one of the flaws of Cameroonian democracy, and one of the structuring slanting of its local governance, the appointment of municipal executives.

The local Cameroonian is therefore obviously democratically and autonomously in immersion, notwithstanding the perverse effects of the nominal act. To the extent that the nomination is dichotomous to democracy, because the one who is appointed is not the product of a popular will, but rather that of an individual. And in return or in return, he owes obedience, dedication and loyalty. In this logic, the nominee remains under the rule of the nominator; he therefore serves his interests and not those of the people.

The problem of appointing municipal executives is more complex in the sense that the delegate of the appointed government is not accountable to the people they are represented, as the leader of a decentralized local authority moved by a specific local interest.

Decentralization also aims to protect specific local interests, which are not opposed to national interests. When a leader of a local authority is not elected, it becomes rather difficult to reconcile the two types of interests and to preserve them.

This is what is known in law as a conflict of interest, sometimes dependent on rash mimicry ${ }^{50}$. However, the local elected representative although not excelling in the perfection of defence of a particular local interest will, all the same tend to preserve it, were it for the exclusive purposes of renewing the confidence in him granted by the people or better his electorate. It is the knot of distinction between the exercise of a function by social agents, thus depending on their origin, which may be elective or politico-administrative, and structure of links of strong interdependence, even of dependence between exercising of the function and the provider of said function.

\section{B-The persistence of political autochthony.}

This part of our work which relates to the reigning indigenousness at the local level in general and in particular within the communes requires a deep sociological ${ }^{51}$, even anthropological, examination of the municipal executives, based on statistical tables with a chronological timetable, determined. We will take two or three cases of municipalities in the political or economic capital or outside. The demonstration of local political autochthony can only be plausible and efficient by relying on the organs of the leaders who exercised the mayoral function using a precise chronological scale.

The law ${ }^{52}$ establishing the conditions of eligibility of municipal executives in general, and municipal councillors in particular, does not explicitly mention this sociological strain on candidates for the election of a mayor or a municipal councillor. And this politico-autochthonic logic tends to gain more and more the local Cameroonian in the sense that it is difficult, even almost impossible to see a mayor or a councillor who is not a son of the district occupying these functions.

Even within the electorate, this rationality becomes more embedded. Consequently, it becomes very improbable to see a non-native ${ }^{53}$ exercise an elective function in a locality from which he did not come. Voters therefore tend to vote only for candidates with whom they have identical ethnic affiliations. However, such a paradigm accepts de facto ethnic presuppositions in the game of democracy. He considers that the democratic system organizes and encourages ethnic discrimination in the allocation of elective functions and that citizens have an interest in it because it allows them to defend their personal interests.

\footnotetext{
49-Roje Tadjie, « Le contrôle des collectivités territoriales décentralisées au Cameroun », op.cit, pp.147-150.

50-Maurice Kamto, Pouvoir et droit en Afrique Noire : Essai sur le constitutionnalisme des Etats d'Afrique Noire francophone, Paris, LGDJ, 1987, p.69.

51-Alain Didier Olinga, " L'exigence de la prise en compte des composantes sociologiques de la circonscription en droit électoral camerounais $"$, in juridis périodique $n^{\circ} 28$, octobre-novembre-décembre, 1996, pp.67-72.

52 -Law $n^{\circ} 92 / 002$ of 14 th august 1992 handling the election conditions of municipal councilors

${ }^{53}$-According to the case law of the Hellenic council of State (Greece), "By non-native, we understand, who has obtained in any way the Hellenic nationality, draught his back-ground origin or not the people belonging the different nation, by the subsidiary actions and his behavior in general, expressed his lacks of national conscience, in the manner that, he cannot be considered as an assimilated member of Greece that constituted related by the common historical traditions and the common ideals". See CE, 57/1981, in P. PAZARTZIS, ibid., note 43.
} 
However, it should be emphasized, there is no absolute correlation between community belonging and sense of voting: the voter, whether African or Cameroonian, does not necessarily decide according to "primordialist" motivations, "utilitarian" considerations Can cause him to change the direction of his vote, and to vote for a candidate or even a political party different from his reference or ethnic ${ }^{54}$ group. He will not always vote mechanically in favour of which, he has the same ethnic, political or even religious connotation.

However, at the local Cameroonian level, it is easy to see that the same elected officials from the political constituency systematically ${ }^{55}$ return. There are candidates for these elections whose origins are not intrinsic to the political constituency sought, and who do not always have the possibility of running for an elective mandate at the local level, because of their origins. This autochthony is structured first of all within political formations where, the non-natives hardly have access to the posts of high political responsibilities, occupying politically and mainly lower levels.

Local governance therefore seems to be at odds ${ }^{56}$ with the ideals of national unity and integration, which at least remain wishful thinking for local political actors. The distrust of the local electorate towards "foreigners" is becoming more and more the political thorn in public sub-state entities. Sometimes the instrumentalization of origins for political and political ends by local political actors further fuels this indigenous resentment towards certain local applicants for these elective functions.

One of the effects of this persistence of local political autochthony is that in several Cameroonian communes, the most politically important positions are and have always been occupied by the natives.

But this problem of the autochtonization of elective functions constitutes a serious handicap for local democracy. The latter is engulfed in a discriminatory labyrinth where, the so-called foreign political actors have no chance to exercise functions of this ilk.

However, the latter contribute to the socio-economic development of their residential localities, indigenous peoples being most often exhibited during periods of political competition. This allegedly positive political discrimination can only alter the process of democratization of the local and kick in the face of the ideals of national unity and integration advocated by the Biya regime. And local political actors purposely instrumentalize this autochthony, the aim being the monopolization of the local political field, thus appearing to be a reserved ${ }^{57}$ area.

On the other hand, it is completely wrong to think that it is an indigenous person who can best defend the interests of his locality. There are Cameroonian municipal executives who show real political mercenary ${ }^{58}$. The materialization of its programmatic offer when it exists, being diametrically opposed to the real local interests of the populations. This situation can be explained, in part, by the incompetence or ignorance of the rules regulating the functioning of the municipal institution in particular, and of decentralization in general.

However, political competitiveness must be the paradigmatic compass in modern political governance, with a view to improving the well-being of citizens, going beyond all political or socio-cultural considerations. This is also one of the keys to the good governance targeted by decentralizing political tendencies, which the Cameroonian municipal institution does not endorse.

In reality, local authorities in the agreement process which is at the heart of the institutional mechanism of decentralized cooperation remains very subsidiary, even non-existent.

Struck upstream by the cohort ${ }^{59}$ of coordination and control bodies overseen by the central state and downstream by the endogenous structural biases of local governance which weigh more heavily on both its visibility and its practice.

In any case, attempts to democratize local political life have prompted an international change in the status of local authorities. Decentralized cooperation would have been the determining variable in this dynamic. However, there are many

\footnotetext{
54-Roger Otayek, « La démocratisation locale entre mobilisation identitaire et besoin d'Etat », in Revue Autrepart, $n^{\circ} 10$, 1999, p.24.

55 -The case of subdivision council of Yaoundé II for example.

${ }^{56}$-See the constitutional reform of 18th January 1996 in Cameroon.

57-Jean Njoya, op, cit, p.28.

${ }^{58}$-Roger Gabriel Nlep, l'Administration publique camerounaise..., op.cit, p.106.

59-It talks mainly about the ministries of decentralization and local development, external relations, Economy, of planification, and fitting of territory and the coordination organs like the national council of decentralization (NCD), interministerial committee of local services (ICLS), and interministerial committee of decentralized cooperation (ICDC).
} 
ways to get around this autonomic transformation of local communities: the central power multiplying bottlenecks which inspire the dark foreboding of an Arles woman.

In any event, the path of reform is now mapped out; but it takes time and as the old saying of the sage teaches us: "time does not spare what is done without it". He is the master of the falsification of all scientific research. 